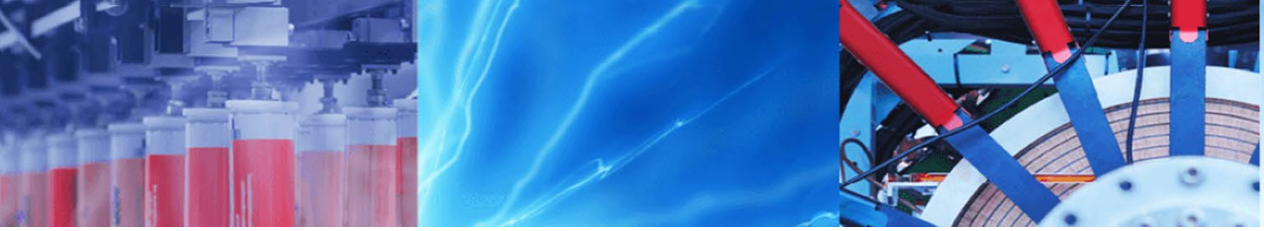

Research Article

\title{
An experimental study on fly ash with lime and gypsum for quality improvement in pavement subgrade materials
}

\author{
Pinak Ray ${ }^{1,2} \cdot$ Amarabati Paul $^{2} \cdot$ Sourav Ghosh $^{2} \cdot$ Kanisha Sarkar $^{2} \cdot$ Ranendra Narayan Sen $^{3}$
}

Received: 28 July 2020 / Accepted: 6 November 2020 / Published online: 12 November 2020

(c) Springer Nature Switzerland AG 2020

\begin{abstract}
Characteristics of pavement subgrade materials play a paramount role in determining the quality and longevity of a pavement. An experimental study has been undertaken to improve such subgrade material on addition of fly ash (percentage of addition 9.7-30\%) as main additive. Two broad sets of samples have been mixed with varying proportions of moorum, silver sand, fly ash mix with stabilizer, i.e. lime and gypsum (percentage of addition from 2 to $3 \%$ ) for one set, and another set of samples where it consists of moorum, silver sand and soil mix (percentage of addition 10-30\%) without fly ash and stabilizer. For each set of sample, the main broad constituent materials have been taken as moorum and silver sand which have percentage of variations $47.53-70 \%$ and $20.37-30 \%$, respectively, because they are the main constituents for pavement subgrade material. To investigate the effects of addition of these stabilizers to assess whether it improves the performance of pavement subgrade materials Proctor tests, CBR and UCS tests have been done on both types of soil samples. The test results have shown that lateritic soil like moorum with silver sand used with addition of stabilizer as a sub-base materials of pavement can be used as a better replacement of commonly used graded traditional coarse aggregate and fly ash used as fines has shown better replacement of local soil. A high correlation coefficient indicates that the CBR value can be well predicted from UCS test results.
\end{abstract}

Keywords Pavement subgrade · Fly ash · Stabilizer · California bearing ratio (CBR) · Proctor test · Unconfined compression strength (UCS) test

\section{Introduction}

India has second largest road network in the world. Most of the roads in India are rural roads and district roads consisting of approximately $26,50,000 \mathrm{~km}$. These rural and district roads used to be constructed by using low cost and widely available local cheap construction materials, out of which most of the commonly used road material is moorum. Moorum is a reddish brown-colored granular soil, mainly a form of lateritic soil, having a certain percentage of fine content. Moorum when mixed with sand, a good subgrade material for low-cost pavement construction would have been developed. But during long-term progressive usage, its strength gets deteriorated gradually. In heavy rainy season, when water gets percolated to the subgrade soil, heaving of the pavement along with severe surface cracking has been observed due to its swelling characteristics, which leads to the deterioration and failure of the pavement. This subgrade material (moorum-sand mix) does not possess long-term durability and longevity. Also repeated application of long-term dynamic loads due to moving vehicles creates rutting failure of the pavement, as the subgrade material does not have sufficient resistance against repeated moving vehicular load as well

$\triangle$ Pinak Ray, pinak.r@technoindiaeducation.com; pinak.ray@gmail.com | 1Jadavpur University, Kolkata, West Bengal 700032, India. ${ }^{2}$ Techno India University, West Bengal, Kolkata, West Bengal 700091, India. ${ }^{3}$ Om Sai Ram RSP Projects Pvt. Ltd, Jamshedpur, Jharkhand 831011, India. 
as this subgrade material does not have sufficient shear strength. An extensive and good quality road network stands as one of the major parameters for the development of a country's social and economic condition. Major hurdles like constraint of fund, lack of good quality construction materials in the near vicinity considerably hamper the process. The basic necessity for a good quality road structure is strong and durable subgrade over which the road is constructed. But in many parts of the country, the sub-soil is of poor quality due to low strength and high compressibility. Also there is scarcity of good-quality conventional construction material for subgrade and base of the road structure. These construction materials mainly include local clayey soil, silver sand, moorum, construction garbage, waste materials, etc. Also the construction method should ensure minimum expenditure with good road quality. As such one option is to use waste materials which arise from different sectors such as domestic, industrial, mining etc. which are cheaply available (like: fly ash, bottom ash, pond ash etc.). The burning of pulverized coal in thermal power plants results in the production of huge quantum of coal ashes namely fly ash and bottom ash. The wet disposal of these ashes separately or in combination in storage ponds results in pond ashes. To improve the soil subgrade pavement materials, the use of industrial waste which is fly ash (available at almost free of cost from the thermal power plant areas) and its combination with cheap and widely available cementing compound like fly ash and gypsum has become very much necessary for good quality and durable pavement construction.

\section{Literature review}

Pulverized coal bottom ash (PCBA), when added with soil with cement as stabilizer, has shown a better improvement in soil properties from UCS and CBR tests at 5\% PCBA content (optimum), which proves the stabilization of tropical black clay soil [1]. An experimental study has been conducted to study the effect of class $C$ fly ashes for the stabilization of expansive soil, by adding Soma fly ash and Tuncbilek fly ash at $0-25 \%$ to the expansive soil by [2]. The results have shown that the plasticity index, activity and swelling potential of the samples decreased with increasing percent stabilizer and curing time and the optimum content of fly ash has been found to be $20 \%$, and it has been recommended that-low calcium class $C$ fly ashes can be recommended as effective stabilizing agents for improvement for improvement in expansive soils [2]. The effect of two types of fly ashes Raichur fly ash (Class F) and Neyveli fly ash (Class C) on the CBR characteristics of the black cotton soil has been studied experimentally by increasing the fly ash content from 0 to $100 \%$ by [3].
Initially the low CBR of black cotton soil was attributed to the inherent low strength, due to the dominance of clay fraction, but the addition of fly ash to black cotton soil increases the CBR of the mix up to the first optimum level due to the frictional resistance from fly ash in addition to the cohesion from black cotton soil and further addition of fly ash beyond the optimum level causes a decrease up to $60 \%$ and then up to the second optimum level there is an increase which signifies that the variation of CBR of fly ash-black cotton soil mixes can be attributed to the relative contribution of frictional resistance on black cotton soil [3]. A study has been conducted to find the CBR value of the red earth on addition of Neyveli fly ash, and it has been observed that pozzolanic reactivity of the Neyveli fly ash increased the CBR value of the earth more after soaking, compared to soil mix without soaking, where the maximum CBR value has been obtained at an addition of $80 \%$ fly ash content [4]. The effect of fly ash lime-fly ash on the index and engineering properties of expansive soils has been investigated, and it was established that addition of fly ash to the soil increased the shrinkage limit and CBR value but decreased the swelling pressure [5]. The effectiveness of using high calcium fly ash and cement in stabilizing fine-grained clayey soils in the laboratory has shown an enhancement of mechanical properties such as flexural strength, modulus of elasticity and CBR values, which signifies that pavement structures incorporating subgrades improved by in-situ stabilization with fly ash and cement, compared with conventional flexible pavements without improved subgrades clearly showed the technical benefits of stabilizing clayey soils with fly ash and cement [6]. A new concept was proposed to determine applicability of two by-products of industry, i.e. phosphogypsum and fly ash with addition of cement for soil stabilization by conducting Atterberg's limit tests, standard proctor compaction tests and unconfined compressive strength tests on cement, fly ash and phosphogypsum-stabilized soil samples, and it was found that treatment with cement, fly ash and phosphogypsum reduces the plasticity index and the maximum dry unit weight increased as cement and phosphogypsum contents increased, but decreased as fly ash content increased and the unconfined compressive strengths of untreated soils were in all cases lower than that for treated soils [7]. Another concept of using stabilizer as lime (added 0-8\%), natural pozzolana (added $0-20 \%$ ) or a combination of both has been introduced to study its effects on geotechnical characteristics of two cohesive soils by conducting standard proctor compaction tests and direct shear tests and the test results indicated that instead of using individually, combination of lime-natural pozzolana has shown higher shear strength parameters (cohesion and angle of internal friction) with curing period [8]. The effect of lime stabilization on the strength 
and durability aspects of a class $F$ pond ash, with a lime constituent, was studied experimentally by conducting UCS tests along with point load strength tests, rebound hammer tests and slake durability tests, and it was found that UCS values of 4.8 and $5.8 \mathrm{MPa}$ and slake durability indices of 98 and $99 \%$ were achieved after 180 days of curing for samples, stabilized with 10 and $14 \%$ lime, respectively [9].

\section{Objective}

The improvement in engineering properties (mainly resistance against rutting failure, swelling characteristics and shear strength) of this moorum-sand mixed lowgrade cheap road material has been considered immense important in the field of transportation infrastructure geotechnical engineering. The materials which have been considered in this experimental study are industrial waste products-fly ash from coal-based thermal power plants (widely available in massive amount in India) along with lime and gypsum. Most of the ashes generated are disposed off in the vicinity of the power plant as a waste material covering several hectares of valuable land. The fly ash creates environmental hazards by polluting air, surface water and contaminating groundwater. Its bulk utilization is possible in the field of road construction works by using the fly ash in subgrade and also as sub-base material of road structure [10]. It has been observed that, coal ashes have advantageous properties such as lower compressibility, higher rate of consolidation, high strength, high CBR, high volume stability, water insensitiveness to compaction and pozzolanic reactivity [11]. The use of coal ashes having these beneficial properties, which are being considered as industrial wastes, serves as a very useful material in the field of geotechnical engineering.

Lime and gypsum are cementing materials, which fill the void spaces between the soil particles and make a good bond between soil particles. Due to hydration of lime a strong bond between the soil particles gets formed. When lime is added to soil, gradual development of strength of the soil mixture occurs along with curing periods. Apart from this, lime and gypsum both are cheap available materials all over in India. Though from research works of previous researchers, it has been established the bonding action along with impermeability and durability and improvement in shear strength is greater developed if cement is added with soil instead of lime and gypsum. But the cost of cement is very much higher with respect to lime and gypsum. In low per capita income country like India, when thousands of kilometres of roads are constructed, the amount of cement which will be required to be mixed along with subgrade soil would be very high.
This will make the cost of the project too much higher. So, if lime can be used instead of cement, it will be cheap, cost effective and economic and would be feasible for budget approval from the government or statutory bodies.

In this regard, a detail experimental study has been performed on moorum-silver sand mixes in addition of fly ash with or without stabilizer (lime or gypsum) by performing modified proctor test, California bearing ratio tests and unconfined compression strength tests. A comparative study of changes in those engineering properties has been reported if locally available soil would be mixed in the replacement of fly ash-lime/gypsum stabilizer with moorum-silver sand mix.

\section{Materials}

\subsection{Moorum}

Moorum is basically a reddish brown-coloured granular soil having the percent fines relatively much higher. It is a deposit of earth material which is formed from the disintegration of igneous and metamorphic rocks, naturally occurring with varying proportions of silt and clay. Moorum is used generally as a low-grade cheap marginal material for road construction. Locally available moorum from Salboni, West Midnapur (West Bengal), India has been collected and used for the investigation. Index and engineering properties of collected moorum determined in the laboratory and the detail test results shown in Table 1.

\subsection{Silver sand}

The types of sand used in the study are medium fine silver grey sand (Hooghly River channel deposit) collected from Diamond Harbour (West Bengal), India. Detailed Engineering properties of sands have been represented in Table 2 .

Table 1 Index and engineering properties of moorum

\begin{tabular}{|c|c|c|c|}
\hline SI No & Characteristics & & Value \\
\hline 1 & Specific gravity & & 2.64 \\
\hline \multirow[t]{3}{*}{2} & \multirow[t]{3}{*}{ Particle size distribution (\%) } & $4.75-0.075 \mathrm{~mm}$ & 45.00 \\
\hline & & $0.075-0.002 \mathrm{~mm}$ & 35.97 \\
\hline & & $<0.002 \mathrm{~mm}$ & 19.03 \\
\hline 3 & Liquid limit (\%) & & 40.54 \\
\hline 4 & Plastic limit (\%) & & 23.36 \\
\hline 5 & Plasticity index (\%) & & 17.18 \\
\hline 6 & Maximum dry density $\left(\mathrm{gm} / \mathrm{cm}^{3}\right)$ & & 2.05 \\
\hline 7 & Optimum moisture content (\%) & & 11.00 \\
\hline 8 & \multicolumn{3}{|c|}{ Moorum classified as a form of reddish brown lateritic soil } \\
\hline
\end{tabular}


Table 2 Engineering properties of silver sand

\begin{tabular}{llll}
\hline SI No & Characteristics & Value \\
\hline 1 & Colour & & Greyish white \\
2 & Specific gravity & Sand & 2.73 \\
3 & Particle size distribution $(\%)$ & Silt $(0.075-0.002 \mathrm{~mm})$ & 85.50 \\
& & Clay $(<0.002 \mathrm{~mm})$ & 12.10 \\
& & & 1.40 \\
4 & Uniformity coefficient $\left(C_{\mathrm{u}}\right)$ & & 3.00 \\
5 & Coefficient of curvature $\left(C_{\mathrm{c}}\right)$ & & 2.08 \\
6 & This sand is classified as silty sand & & \\
\hline
\end{tabular}

Table 3 Engineering properties of fly ash used

\begin{tabular}{llll}
\hline SI No & Characteristics & & Value \\
\hline 1 & Colour & & Grey \\
2 & Specific gravity & & 2.25 \\
3 & Particle size distribu- & $>0.075 \mathrm{~mm}$ & 7.30 \\
& tion (\%) & $0.075-0.002 \mathrm{~mm}$ & 88.70 \\
& & $<0.002 \mathrm{~mm}$ & 4.00 \\
\hline
\end{tabular}

Table 4 Chemical composition of fly ash used

\begin{tabular}{lc}
\hline Name of constituents & $\begin{array}{l}\text { Constituents } \\
\text { by weight (\%) }\end{array}$ \\
\hline $\mathrm{SiO}_{2}$ & 40.60 \\
$\mathrm{Al}_{2} \mathrm{O}_{3}$ & 19.06 \\
$\mathrm{Fe}_{2} \mathrm{O}_{3}$ & 5.34 \\
$\mathrm{CaO}$ & 24.00 \\
$\mathrm{MgO}$ & 2.00 \\
$\mathrm{SO}_{3}$ & 3.00 \\
Loss on ignition & 6.00 \\
\hline
\end{tabular}

\subsection{Fly ash}

Fly ash, collected from National Thermal Power Corporation Limited (NTPC), Farakka (West Bengal), India, has been used in this present investigation. Evaluated engineering properties of the fly ash have been shown in Table 3, and the chemical composition of fly ash has been shown in Table 4.

\subsection{Locally available soil}

Soil used in the present investigation collected from a construction site near Garia, Kolkata (West Bengal), India. On the basis of grain size distribution, this locally available soil has been found to be light grey clayey silt. Physical properties of the soil have been shown in Table 5. Based on liquid limit and plasticity index, the soil may be classified as $\mathrm{CL}$ (Clay-low compressibility).
Table 5 Index and engineering properties of locally available soil

\begin{tabular}{|c|c|c|c|}
\hline SI No & Characteristics & & Value \\
\hline 1 & Specific gravity & & 2.67 \\
\hline \multirow[t]{3}{*}{2} & \multirow[t]{3}{*}{ Grain size distribution (\%) } & Sand (4.75-0.075 mm) & 6.08 \\
\hline & & Silt (0.075-0.002 mm) & 78.92 \\
\hline & & Clay $(<0.002 \mathrm{~mm})$ & 15.00 \\
\hline 3 & Liquid limit (\%) & & 31.80 \\
\hline 4 & Plastic limit (\%) & & 21.40 \\
\hline 5 & Plasticity index (\%) & & 10.40 \\
\hline 6 & IS soil classification group & hbol & $\mathrm{CL}$ \\
\hline 7 & Maximum dry density (gm & & 1.85 \\
\hline 8 & Optimum moisture conten & & 14.00 \\
\hline
\end{tabular}

Table 6 Chemical composition of hydrated lime

\begin{tabular}{lc}
\hline Name of constituents & $\begin{array}{l}\text { Constituents } \\
\text { by weight (\%) }\end{array}$ \\
\hline $\mathrm{SiO}_{2}$ & 4.11 \\
$\mathrm{Al}_{2} \mathrm{O}_{3}$ & 3.11 \\
$\mathrm{Fe}_{2} \mathrm{O}_{3}$ & 2.70 \\
$\mathrm{CaCO}_{3}$ & 3.80 \\
$\mathrm{CaO}$ & 63.70 \\
$\mathrm{CaSO}$ & 19.26 \\
$\mathrm{MgO}$ & 1.62 \\
Loss on ignition & 1.70 \\
\hline
\end{tabular}

\subsection{Lime}

Quick lime, sprinkled with water slaked within $10 \mathrm{~min}$ and the fine powder obtained in the process called hydrated lime. The process is known as hydration of lime. Hydrated (slaked) lime is very useful and effective in treating heavy, plastic clayey soils. Lime reduces the shrinkage-swelling properties of expansive soil. As a result, the plasticity index of soil increases (Table 6). 
Table 7 Chemical composition of gypsum

\begin{tabular}{ll}
\hline $\begin{array}{l}\text { Name of con- } \\
\text { stituents }\end{array}$ & $\begin{array}{l}\text { Constituents } \\
\text { by weight (\%) }\end{array}$ \\
\hline $\mathrm{CaSO}_{4}$ & 86.12 \\
$\mathrm{SiO}_{2}$ & 10.02 \\
$\mathrm{Al}_{2} \mathrm{O}_{3}$ & 0.85 \\
$\mathrm{Fe}_{2} \mathrm{O}_{3}$ & 0.47 \\
$\mathrm{NaCl}_{\mathrm{CaCO}}$ & 0.05 \\
$\mathrm{MgCO}_{3}$ & 2.47 \\
\hline
\end{tabular}

\subsection{Gypsum}

Gypsum a non-hydraulic binder occurs naturally as a soft crystalline rock. Pure gypsum, a white translucent crystalline mineral is soft and it can be scratched by a finger nail. The composition of pure gypsum may be represented adequately by the formula $\mathrm{CaSO}_{4}$. As mined, the gypsum contains with a number of impurities, such as silica and other earthy materials like calcium and magnesium carbonates, iron oxide, alumina etc. The chemical composition of gypsum has been represented in Table 7. From the result of chemical analysis, it has been observed that along with major percentage of $\mathrm{CaSO}_{4}(86.12 \%)$ there exists impurities in the gypsum. It has been observed that the major impurity $\mathrm{SiO}_{2}$ was $10.02 \%$ and the rest of the impurities were less than $4 \%$.

\section{Materials and methods}

Detailed experimental study was undertaken to investigate the maximum dry density, optimum moisture content, swelling potential, shear strength and CBR values of typical locally available moorum, silver sand, soil mixed with lime, gypsum and coal-based thermal power plant ash (fly ash) in different percentages and in several combinations to determine the applicability of such materials in pavement subgrade. In this regard, the name of the experimental procedures has been undertaken in this present study on the basis of the relevant IS codes which were followed and have been listed in Table 8. All the tests were carried out as per the procedures laid out in the relevant IS codes of practice given in Table 8.

Based on this point of view, the present experimental study has been aimed at to investigate the behaviour of soils with addition of alternative materials with the range of each addition making clearly specified and this has been detailed in Table 9. It can be stated that broadly total 7 sets of soil samples have been prepared in this present study. Based on the soil mix sets represented in Table 9, a clear idea on detailed mix proportion of moorum, sand, fly ash mix with or without lime and gypsum and moorum, silver sand and soil mix without stabilizer which have been shown in Table 10 and Table 11 can be understood and correlated.
Table 8 Name of tests performed and relevant IS Code followed

\begin{tabular}{lll}
\hline SI. No & Name of tests & Relevant IS code followed \\
\hline 1 & Specific gravity & IS: 2720, Part-III, 1980 [17] \\
2 & Classification and identification of soil & IS: 1498,1970 [18] \\
3 & Grain size analysis & IS: 2720, Part-IV, 1985 [12] \\
4 & Atterberg's limits & IS: 2720, Part-V, 1985 [19] \\
5 & Water content determination & IS: 2720, Part-II, 1973 [15] \\
6 & Water content-dry density relationship using heavy & IS: 2720, Part-VIII, 1983 [14] \\
& compaction & \\
7 & Test for swelling potential & IS: 2720, Part-XVI, 1987 [13] \\
8 & California bearing ratio & IS: 2720, Part-XVI, 1987 [13] \\
9 & Unconfined compression strength tests & IS: 2720, Part-X, 1991 [16] \\
\hline
\end{tabular}

Table 9 Test mixes prepared for experimental study

\begin{tabular}{|c|c|c|c|c|c|c|c|c|}
\hline \multirow{3}{*}{$\begin{array}{l}\text { Set No } \\
\text { Set } 1 \\
\text { Set } 2\end{array}$} & \multicolumn{4}{|c|}{ Major constituents in the mix along with percentage } & \multicolumn{4}{|c|}{ Fly Ash/Stabilizer/Soil percentage } \\
\hline & Moorum & $70 \%$ & Silver Sand & $30 \%$ & \multicolumn{4}{|c|}{ No Fly Ash/Stabilizer/Soil added } \\
\hline & Moorum & $67.9-68.6 \%$ & Silver Sand & $29.1-29.4 \%$ & Lime & $2-3 \%$ & & \\
\hline Set 3 & Moorum & $67.9-68.6 \%$ & Silver Sand & $29.1-29.4 \%$ & Gypsum & $2-3 \%$ & & \\
\hline Set 4 & Moorum & $49-63 \%$ & Silver Sand & $21-27 \%$ & Fly ash & $10-30 \%$ & & \\
\hline Set 5 & Moorum & $47.53-61.74 \%$ & Silver Sand & $20.37-26.46 \%$ & Fly ash & $9.7-29.4 \%$ & Lime & $2-3 \%$ \\
\hline Set 6 & Moorum & $47.53-61.74 \%$ & Silver Sand & $20.37-26.46 \%$ & Fly ash & $9.7-29.4 \%$ & Gypsum & $2-3 \%$ \\
\hline Set 7 & Moorum & $49-63 \%$ & Silver Sand & $21-27 \%$ & Local soil & $10-30 \%$ & & \\
\hline
\end{tabular}


Table 10 Detailed mix proportion of moorum, sand, fly ash mix with or without lime and gypsum

\begin{tabular}{llllll}
\hline Sample No & Moorum (\%) & Silver Sand (\%) & Fly Ash (\%) & Lime (\%) & Gypsum (\%) \\
\hline 1 & 70 & 30 & 0 & 0 & 0 \\
2 & 68.6 & 29.4 & 0 & 2 & 0 \\
3 & 67.9 & 29.1 & 0 & 3 & 0 \\
4 & 68.6 & 29.4 & 0 & 0 & 2 \\
5 & 67.9 & 29.1 & 0 & 0 & 3 \\
6 & 63 & 27 & 10 & 0 & 0 \\
7 & 61.74 & 26.46 & 9.8 & 2 & 0 \\
8 & 61.11 & 26.19 & 9.7 & 3 & 0 \\
9 & 61.74 & 26.46 & 9.8 & 0 & 2 \\
10 & 61.11 & 26.19 & 9.7 & 0 & 3 \\
11 & 56 & 24 & 20 & 0 & 0 \\
12 & 54.88 & 23.52 & 19.6 & 2 & 0 \\
13 & 54.32 & 23.28 & 19.4 & 3 & 0 \\
14 & 54.88 & 23.52 & 19.6 & 0 & 2 \\
15 & 54.32 & 23.28 & 19.4 & 0 & 3 \\
16 & 49 & 21 & 30 & 0 & 0 \\
17 & 48.02 & 20.58 & 29.4 & 2 & 0 \\
18 & 47.53 & 20.37 & 29.1 & 3 & 0 \\
19 & 48.02 & 20.58 & 29.4 & 0 & 2 \\
20 & 47.53 & 20.37 & 29.1 & 0 & 3 \\
\hline
\end{tabular}

Table 11 Detailed mix proportion of moorum, silver sand and soil mix without stabilizer

\begin{tabular}{llll}
\hline Sample No & Moorum (\%) & Silver Sand (\%) & Soil (\%) \\
\hline 21 & 63 & 27 & 10 \\
22 & 56 & 24 & 20 \\
23 & 49 & 21 & 30 \\
\hline
\end{tabular}

The grain size distribution of silver sand, fly ash, moorum and locally available soil specimens has been done as per [12], and the grain size distribution graph has been shown in Fig. 1. Detailed experimental study has been taken to investigate the degree of compactness, resistance against rutting failure, swelling potential and shear strength of typical locally available moorum, silver sand, local soil mixed with lime, gypsum and coalbased thermal power plant ash (fly ash) in different percentage of combinations. Indian standard codes have been followed for determination of water content-dry density relation to determine their individual OMC and $M D D$, laboratory $C B R$ tests and unconfined compression strength tests on both unstabilized and stabilized sample mixes. Detailed mix proportions have been shown in Table 10 and Table 11. The swelling potential has been measured as per [13] using CBR instrument along with tripod for the expansion measuring device which was mounted at the edge of CBR mould and after preparing specimens in the CBR mould as per [13], maintaining

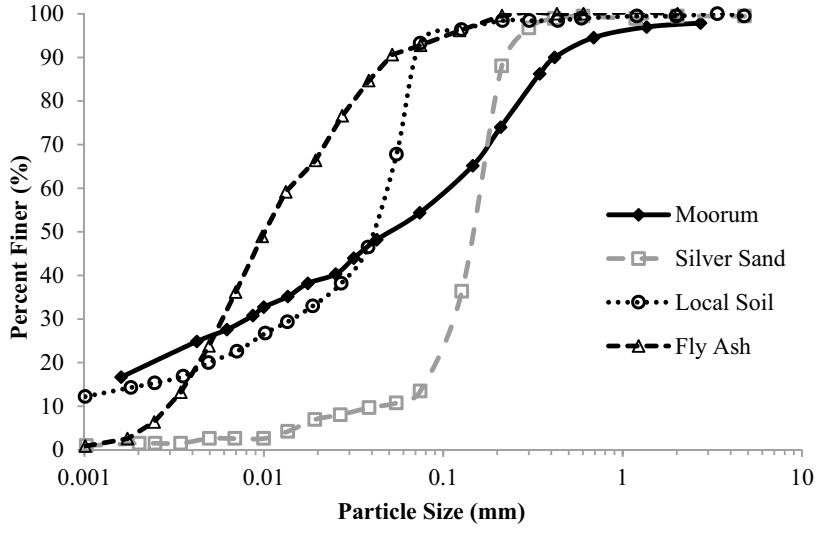

Fig. 1 Grain size distribution graph of fly ash, moorum, silver sand and local soil samples

a constant water level the whole arrangement was immersed in water tank for $96 \mathrm{~h}$. The expansion ratio of the sample has been determined using Eq. 1. The swelling percentage value of a soil can be identified qualitatively by the expansion ratio from this test.

Expansion ratio $=\frac{d_{f}-d_{i}}{h} \times 100$

where $d_{\mathrm{f}}=$ final dial gauge reading in $\mathrm{mm}, d_{\mathrm{i}}=$ initial dial gauge reading in $\mathrm{mm}, h=$ initial height of the specimen in $\mathrm{mm}$. 
For tests of specimens of mixed soils, specimens prepared by thoroughly mixing the required quantity of soil and stabilizers in preselected proportion in dry state and then required quantity of water was sprinkled and mixed thoroughly to get a homogeneous and uniform mixture of soil and admixtures. To investigate the effect of mixing fly ash and stabilizer in moorum sand mix used for construction of road sub-base, fly ash was mixed in various proportions of $10 \%, 20 \%$ and $30 \%$ and in combination of stabilizer in the proportions of $0 \%, 2 \%, 3 \%$, with each of the percentage of fly ash (Table 10). To determine the moisture content dry density relationship, modified proctor compaction tests were carried out. For CBR tests, double numbers of specimens were prepared in the CBR mould as per the standard practice. Both the specimens (for any particular sample no.) were compacted at moisture content equal to OMC value obtained from proctor tests. Immediately after preparation of specimen, it was submerged for four days for soaked tests. The reason was that one sample was taken to carry out CBR test, and another sample was taken to prepare cylindrical soil sample of $38 \mathrm{~mm}$ diameter and $76 \mathrm{~mm}$ height to conduct unconfined compression strength tests. When a sample is in soaked condition for 4 days, it resembles the worst possible field condition. In this field condition, determination of shear strength of the soil has been felt to identify that it was very much necessary and important.

\section{Results and discussion}

Compaction characteristics (OMC and MDD), CBR values and unconfined compression strength of moorum, sand mix with varying percentage of fly ash and stabilizer of sample no. 1 to 20 have been represented in Table 12 and moorum-silver sand mix with varying percentage of soil without stabilizer the compaction characteristics (OMC and MDD), CBR values and unconfined compression strength test results of sample no. 21-23 have been shown in Table 13.

\subsection{Modified proctor test result}

Total 23 numbers of Modified Proctor Compaction tests have been carried out as per [14] for sample no. 1-23. In this section details, Modified Proctor Compaction test results have been represented in Table 12 and Table 13 and the some typical experimental results have been shown and Fig. 2. During each proctor test, the moisture contents of the soil sample have been measured as per [15].

\subsubsection{Effect of fly ash and soil addition on MDD of samples}

From Table 12, graphical representation between MDD with percentages of fly ash and soil mix in moorum-silver sand has been shown in Fig. 3.

The test results (shown in Fig. 3) indicated that between 0 and $30 \%$ fly ash content MDD reduces from $2.425 \mathrm{gm} /$ $\mathrm{cm}^{3}$ to $2.198 \mathrm{gm} / \mathrm{cm}^{3}$. This decrease may be attributed to the replacement of moorum-silver sand mix in the fly ashmoorum-silver sand mixture by fly ash which have relatively low specific gravity (2.25), compared to that of the moorum and silver sand which has a specific gravity of 2.64 and 2.72, respectively. On the other hand, MDD value also decreases with increase in soil percentage but at a lower rate compared to fly ash because soil have relatively higher specific gravity.

\subsubsection{Effect of Stabilizer addition on MDD of samples}

From Table 12 and Table 13, five curves plotted between MDD value and percentage of fly ash for a given percentage of lime or gypsum and without Lime or Gypsum (i.e. $0 \%$ stabilizer added) and have been presented in Fig. 4.

From Fig. 4, it has been observed that with the increase in lime and gypsum contents MDD decreases gradually at a given percentage of fly ash. This decrease may form the flocculation and agglomeration of clay particles caused by cation exchange reaction leading to corresponding decrease in dry density. The decrease in the MDD of the lime-treated soil is reflective of the increased resistance offered by the flocculated soil structure to the compactive effort.

The dry density moisture content relationship of admixture-contained moorum-sand-fly ash/soil has been presented in Fig. 3 and Fig. 4. From the curves, it may be observed that with the increase in fly ash and soil content maximum dry density decreases. Also it was found that with increase in stabilizer content maximum dry density decreases.

\subsection{CBR test results}

Twenty-three numbers of California Bearing Ratio tests have been carried out as [13] for sample no. 1-23. The California Bearing Ratio test results have been represented in Table 12 and Table 13 to find out their relation with varying percentages of soil and fly ash, and some typical experimental results have been shown and Fig. 5 .

The California Bearing Ratio value of each test of soil sample has been obtained by using the ratio of the force per unit area required to drive a cylindrical plunger of $50 \mathrm{~mm}$ diameter at the rate of $1.25 \mathrm{~mm} / \mathrm{min}$ into a soil mass to that required to drive the same plunger at the 


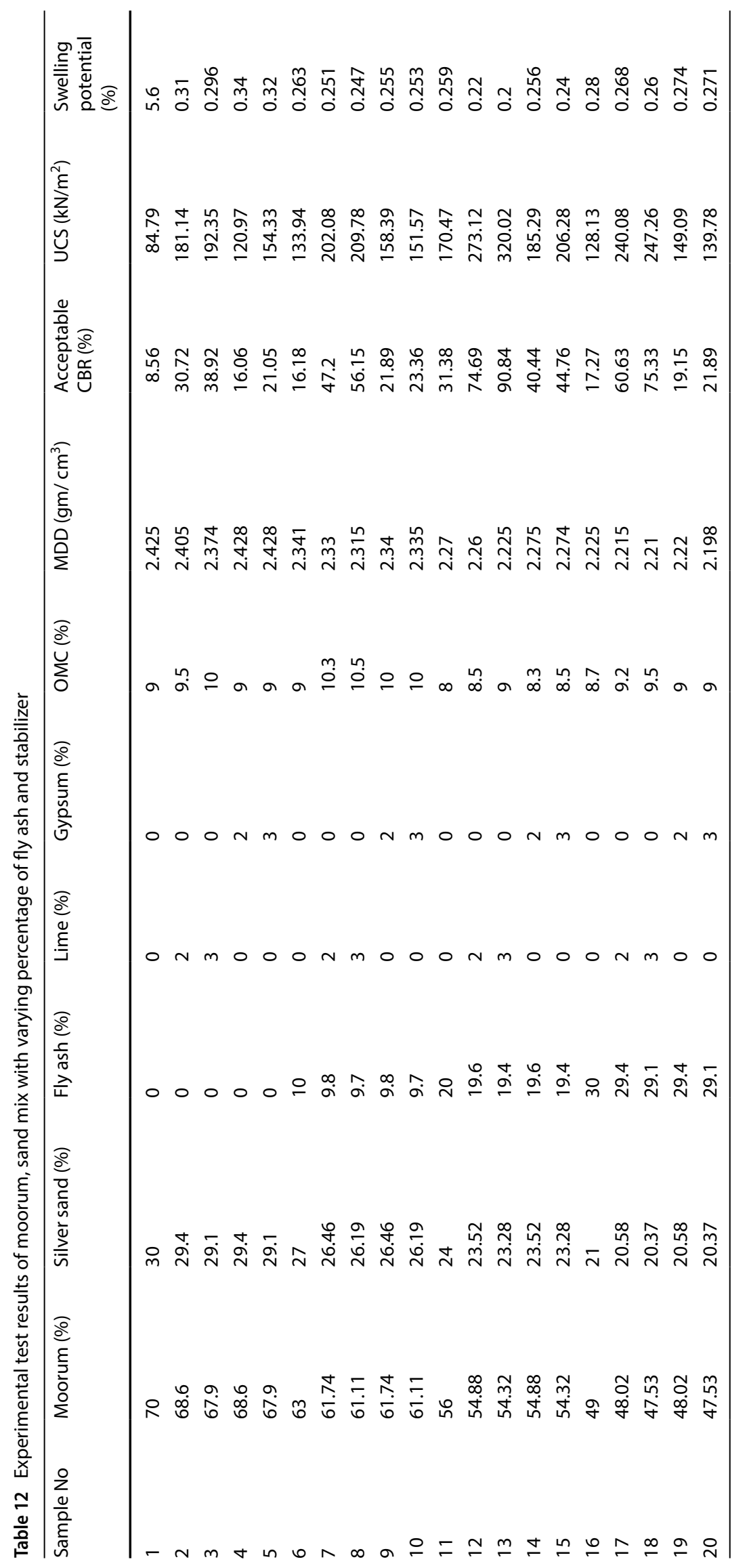


Table 13 Experimental test results moorum—silver sand mix with varying percentage soil without stabilizer Proctor

\begin{tabular}{lllllllcc}
\hline Sample No & Moorum (\%) & $\begin{array}{l}\text { Silver sand } \\
(\%)\end{array}$ & Soil (\%) & OMC (\%) & MDD $\left(\mathrm{gm} / \mathrm{cm}^{3}\right)$ & $\begin{array}{l}\text { Acceptable } \\
\text { CBR (\%) }\end{array}$ & $\begin{array}{c}\text { UCS }\left(\mathrm{kN} / \mathrm{m}^{2}\right) \\
\begin{array}{l}\text { Swelling } \\
\text { potential } \\
(\%)\end{array}\end{array}$ \\
\hline 21 & 63 & 27 & 10 & 8.4 & 2.374 & 11.97 & 106.67 & 5.88 \\
22 & 56 & 24 & 20 & 8.2 & 2.35 & 12.84 & 106.5 & 6 \\
23 & 49 & 21 & 30 & 8.2 & 2.33 & 9.24 & 89.41 & 6.2 \\
\hline
\end{tabular}

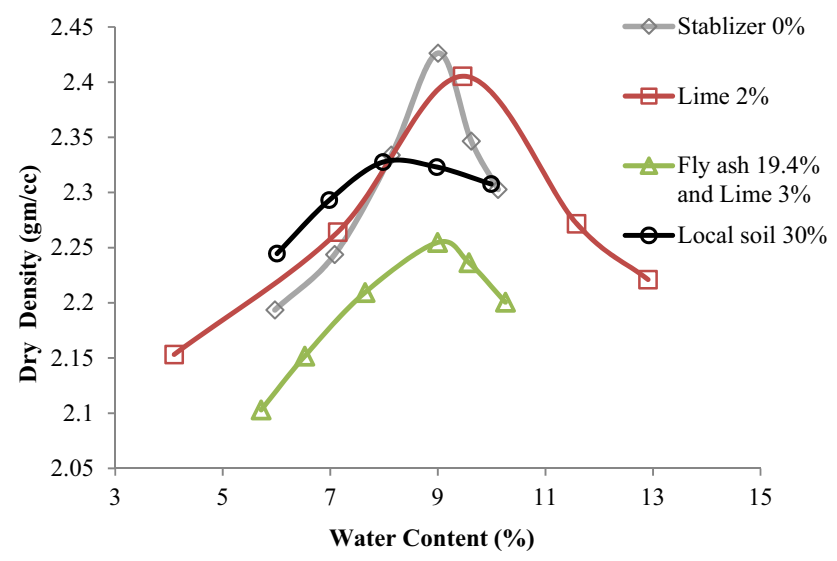

Fig. 2 Modified proctor test results of sample 1, 2, 13 and 23

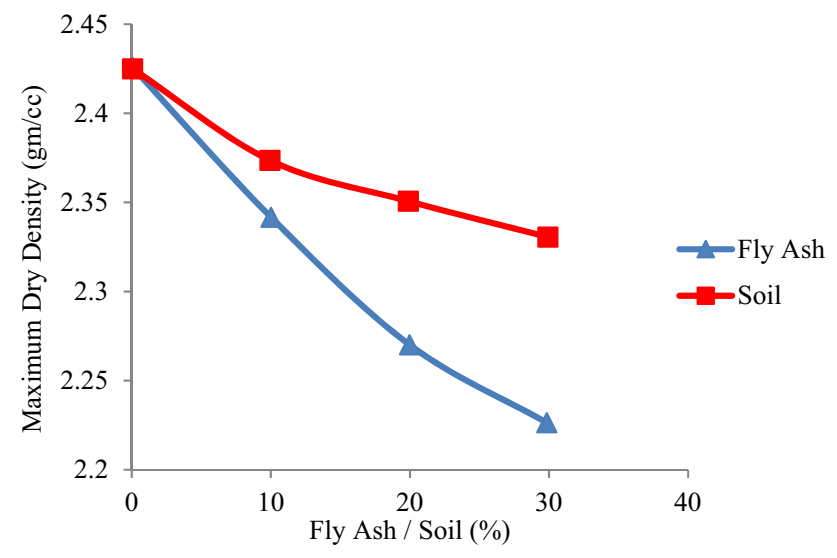

Fig. 3 Variation of maximum dry density with change in fly ash and soil content (\%)

same rate into a standard sample of crushed stone. Thus, the CBR value has been determined for this experimental study by using Eq. 2 .

$\mathrm{CBR}=\frac{\text { Test load }}{\text { Standard load }} \times 100 \%$

From experimental results of CBR tests of soil mix (sample 1 to sample 23), the load-settlement curve has been plotted (four representative graphs have been

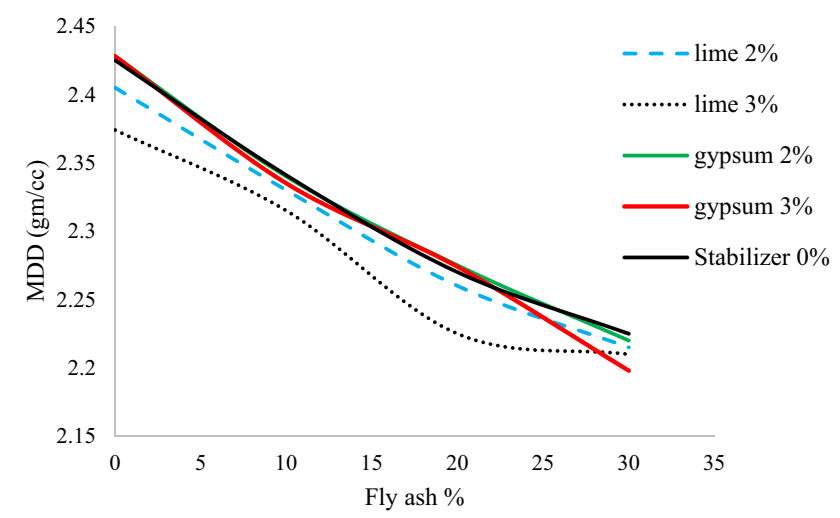

Fig. 4 Variation of maximum dry density with change in fly ash content (\%) at given stabilizer content

shown in Fig. 5). The shape of the curve should be convex upwards (if there is no error due to surface irregularities is present). From each graph, the test loads for $2.5 \mathrm{~mm}$ penetration and $5.0 \mathrm{~mm}$ penetration have been determined. The values of unit standard loads corresponding to these penetrations are $70 \mathrm{~kg} / \mathrm{cm}^{2}$ and $105 \mathrm{~kg} / \mathrm{cm}^{2}$, respectively. Therefore, the CBR value for $2.5 \mathrm{~mm}$ and $5.0 \mathrm{~mm}$ penetration has been determined by using Eq. 2 . If the CBR value at $2.5 \mathrm{~mm}$ penetration is higher than $5.0 \mathrm{~mm}$ penetration then the former value can be considered as final accepted $C B R$ value. But when the $C B R$ value corresponding to $5 \mathrm{~mm}$ penetration exceeds that for $2.5 \mathrm{~mm}$ penetration the test should be repeated. Again if similar kind of result would be obtained the CBR value for $5 \mathrm{~mm}$ penetration should be used as per [13]. It has been found that from the all CBR tests (except sample 20) have shown higher value for $5 \mathrm{~mm}$ penetration than $2.5 \mathrm{~mm}$ penetration, so it has been repeated for checking. But repeat tests again have shown similar result. So $5 \mathrm{~mm}$ penetration $\mathrm{CBR}$ value has been accepted as the final accepted CBR value of the sample material. Four representative test results have been chosen to show in graphical form in Fig. 5.

Generally, the load-penetration graph for CBR test should always be convex upwards (like the graphs obtained for sample 1, 18 and 19) when there is no error would occur during the experiment. But due to surface 

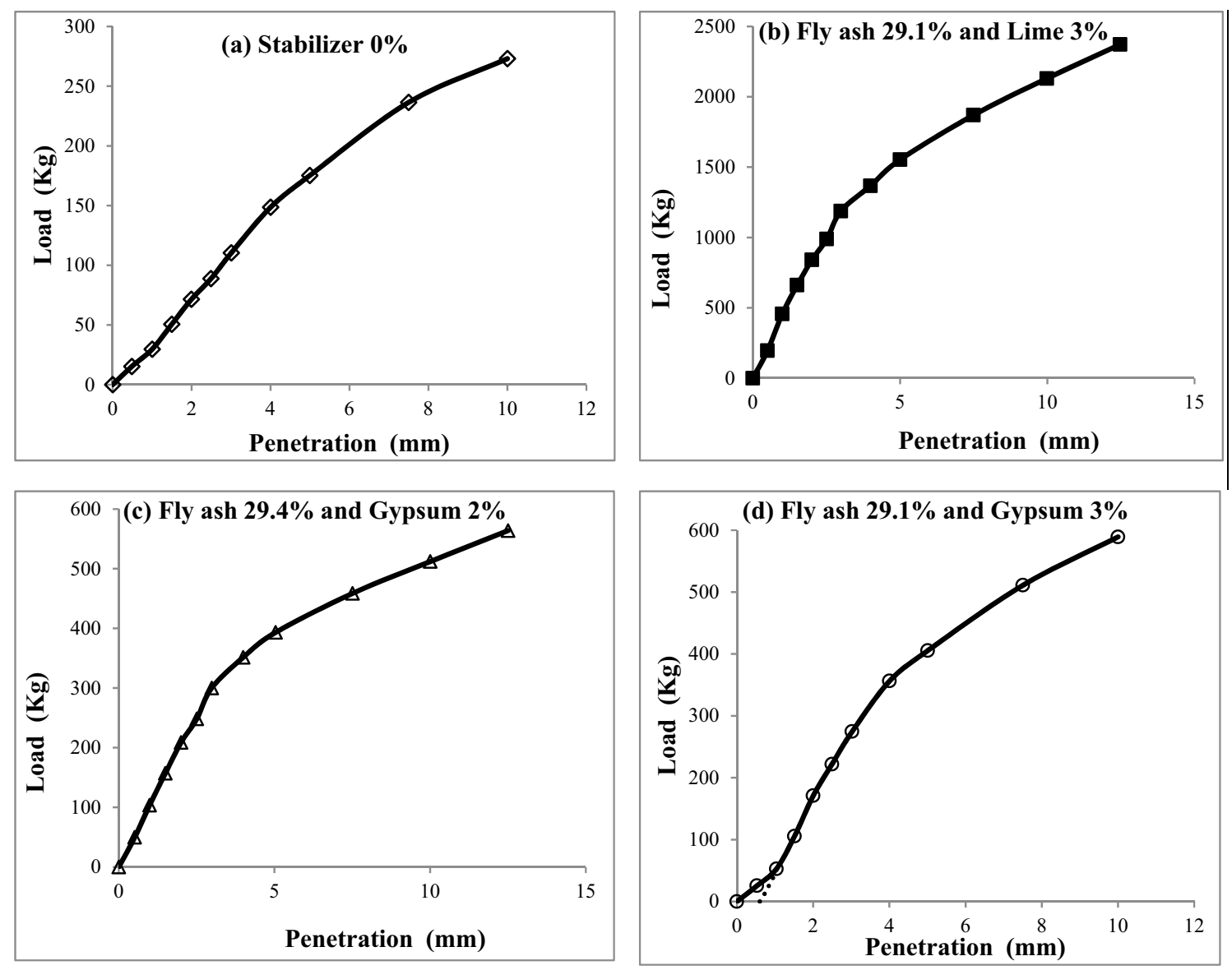

Fig. 5 CBR test results of sample No. 1, 18, 19 and 20

irregularities of a specimen, the initial portion of the curve would be concave upwards (just like the graph of sample 20). The curve then must be corrected by projecting the straight portion of that curve backwards, to meet the $x$-axis at a particular point of intersection. The origin from $(0,0)$, now then become shifted to the point of intersection of the backward projection of straight portion of that curve with $\mathrm{x}$-axis as new origin. Subsequently, all penetrations have been measured from the new shifted origin. This backward projection has been shown by dotted line in the fourth graph in Fig. 5. This type of example of elimination of error has been found during the experiments of sample 4, 5, 9, 10, 15, 16 and 20 . That is why the test result of sample 20 has been incorporated as fourth graph in Fig. 5.

\subsubsection{Swelling potential measured using CBR mould}

From the swelling test results represented in Table 12 and Table 13, it has been observed that for those soil samples without fly ash and stabilizer (lime or gypsum), i.e. sample no. 1, 21, 22 and 23 have shown higher amount of swelling percentage ranges from 5.6 to $6.2 \%$. But for those soil samples which were mixed with either fly ash or stabilizer or both of them have shown very low result of CBR-swelling percent ranges from 0.2 to $0.34 \%$ and the least CBR-swelling percentage was found for the sample where $19.4 \%$ fly ash and $3 \%$ lime was added. So to get the best result of highest reduction in swelling property, the best combination of subgrade material mix should be moorum $54.32 \%$, silver sand $23.28 \%$ along with addition of fly ash $19.4 \%$ and lime $3 \%$.

If fly ash (which is waste product from thermal power plant) along with lime can be premixed and used in addition with pavement subgrade soil, then the chances of swelling of soil can be minimized in a large amount. This combination of pavement soil subgrade material will reduce the maintenance cost of a pavement. This improvement in swelling behaviour can be explained as due to a formation of cementitious compounds which reduces the volume of the void spaces and joined the soil particles together. The cementing property has increased gradually along with hydration of lime. It has been observed after adding lime along with fly ash to the soil the amount of 


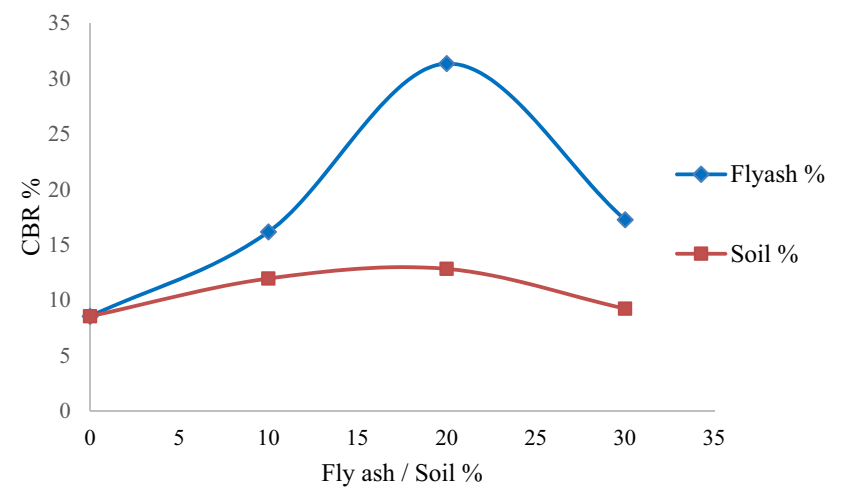

Fig. 6 Variation of soaked CBR values with change in fly ash and soil content (\%)

reduction in swelling percentage was less after 1 day of immersing the soil specimen in water tank, but this swelling reduction has been found $24.67 \%$ higher after 4 days.

\subsubsection{Comparison between CBR values at different fly ash/ soil content without stabilizer}

From the relation in between soaked CBR and percentage of local soil with replacement of fly ash presented in Table 13, the comparative two curves have been shown in Fig. 6 . It has been observed that CBR values increases with addition of fly ash or soil content upto $20 \%$ for both cases and thereafter CBR values start decreasing. But addition of fly ash content, the CBR values increase drastically higher instead of addition of soil content (relatively lower rate of increase of CBR values). This phenomenon explains that fly ash is better ground improvement material can be used in subgrade pavement construction. Fly ash is a cohesionless material and therefore non-plastic in nature, whereas the moorum is cohesive in nature. The gradation and texture of the moorum-silver sand-fly ash mix varied with increase in fly ash content. The deficiency of coarse particles in the moorum has been taken care of by the fly ash particles, resulting in higher frictional strength of the mix resulting higher CBR value (strength against probable rutting failure) than the addition of local soil with moorum-silver sand. It has been observed that addition of fly ash content with moorum-silver sand mix upto $20 \%$ drastically increased the soaked CBR values of the mix. It has been occurred due to improvement in the gradation of the mix along with relative contribution of the frictional resistance in the moorum-silver sand-fly ash mix. But further addition of fly ash content results replacement of silver sand (cohesionless material) by fly ash, another cohesionless material with lesser value of specific gravity, which results decrease in the CBR value of moorum-silver sand-fly ash mix.

\subsubsection{Effect of fly ash addition on CBR of moorum-silver sand mixes with and without stabilizers}

For evaluating the relation in between percentages of fly ash versus 4-day soaked $C B R$ values at different stabilizer content, the comparative five curves have been plotted (shown in Fig. 7). It has been observed that the increase in CBR due to addition of fly ash may be attributed to the gradual formation of cementitious compounds between the fly ash and moorum soil. The decrease in the rate of increase in CBR after 20\% fly ash content may be due to the excess fly ash which was not mobilized in the reaction. The excess fly ash occupies space within the specimen and reduces the clay and silt content in moorum and hence reduces the bond (cohesion) in the soil with fly ash mixture.

\subsubsection{Effect of lime addition on CBR of moorum-Silver Sand-Fly Ash mixes}

The increase in CBR value after addition of lime is due to the formation of various cementing agents is due to pozzolanic reaction between the amorphous silica and/ or alumina present in moorum and silver sand. The main cementing agent is calcium oxide $(\mathrm{CaO})$ which is present in both lime (63.70\%) and fly ash (24\%). Due to addition of fly ash along with lime in the mixture of moorum-silver sand mix for fly ash and lime with an appreciable amount of $\mathrm{CaO}$, hardening takes place in the soaked condition resulting in a higher soaked CBR. In the present study, as the calcium content of the fly ash is high, this phenomenon has occurred. This $\mathrm{CaO}$ makes pozzolanic reaction between the amorphous silica and/or alumina present in moorum and silver sand. This reaction produces stable calcium silicate hydrates and calcium aluminate hydrates which has resulted a higher soaked CBR value.

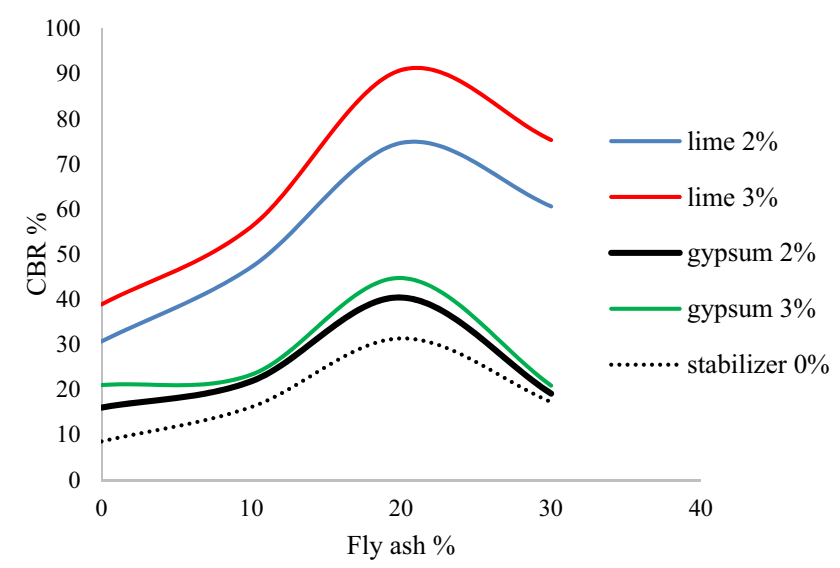

Fig. 7 Variation of soaked CBR with change in fly ash (\%) at given stabilizer content 


\subsubsection{Effect of gypsum addition on CBR of moorum-silver sand-fly ash mixes}

When gypsum was added to the moorum soil mix gives $44.76 \%$ CBR value at $20 \%$ fly ash content which is 1.43 times more than when no stabilizer is used. This is due to the bonds between the soil particle and the cementitious compound formed. Although it gives less CBR value but expected to be high at higher gypsum content.

From Fig. 6, it has been found that fly ash is a good finer material in terms of CBR strength compare to local soil. The $C B R$ curves of individual admixture contained specimens have been presented in Fig. 7. From the general nature of the CBR curves, it has been observed that the CBR values of stabilizer added with moorum-sand-fly ash has been increased with increasing in lime or gypsum content and in all the cases, the lime-stabilized combination soaked CBR is much more than the gypsum-stabilized combination soaked CBR. In case of addition of fly ash at $20 \%$ on moorum-sand mix gives peak CBR value but further increase in fly ash it gives low CBR value. When fly ash is added to the mixes, the strength characteristics also goes on increasing although at a slower rate than limemoorum sand mixed soil. But when lime and fly ash both are mixed, the strength characteristics have much further increased this was due to the influence of pozzolanic reaction between fly ash and free lime and all the cementitious compounds were developed within 4-day curing period.

\subsection{Unconfined compression strength test results}

To determine the shear strength of the soil samples mixed with different proportions with or without stabilizers (Tables 7, 8), unconfined compression strength (UCS) tests have been performed on all the soil samples with the said mix proportions. Total 23 numbers of UCS tests have been done as per [16] and all the test results have been represented in Table 12 and Table 13. The soil samples of $38 \mathrm{~mm}$ diameter and $76 \mathrm{~mm}$ height for UCS tests have been extracted from the specimens prepared for CBR tests in CBR mould, where the specimens were compacted at moisture content equal to optimum moisture content (from modified proctor test) and was kept submerged in water for four days, which resembles the worst possible field condition. Some typical UCS test results have been shown in Fig. 8.

\subsubsection{UCS test results at different Fly Ash/soil content without stabilizer}

The unconfined compression strength values of fly ash/ soil addition with moorum-silver sand mixes without addition of any stabilizer has been shown in Fig. 9. The

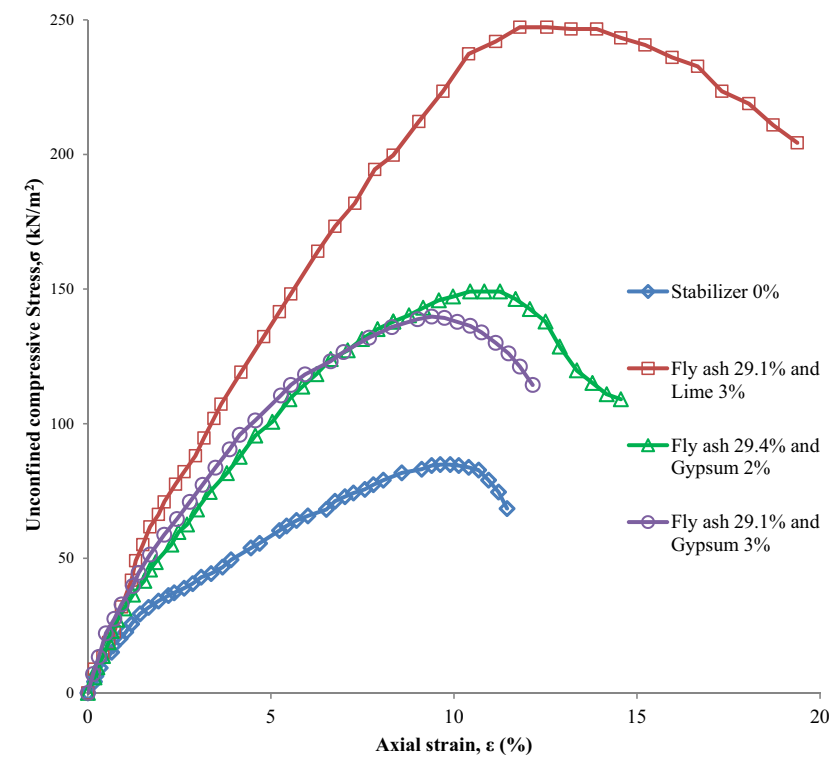

Fig. 8 Unconfined compression strength test results of sample No. $1,18,19$ and 20

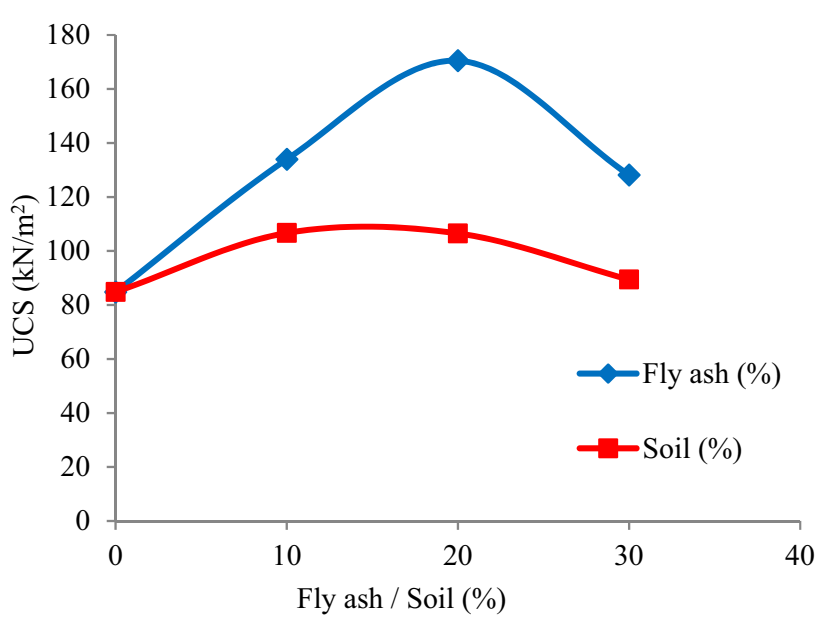

Fig. 9 Variation of unconfined compressive strength with change in fly ash and soil (\%)

test results have shown almost similar pattern of graphical representation of experimental results obtained from soaked CBR tests (Fig. 6). UCS value increases and gained maximum at fly ash content of $20 \%$, and thereafter starts decreasing. But there is very less gradual increase of UCS value in addition of local soil and the UCS value gains a maximum at soil content of $13 \%$ and thereafter it starts decreasing with addition of local soil to the moorum-silver sand mixes. The shear strength of the soil mixes are almost same (a very slight increase of $1.8 \%$ ) for an addition of soil content $=30 \%$. Figure 9 represents that addition of fly ash at $20 \%$, shows a better material for higher 


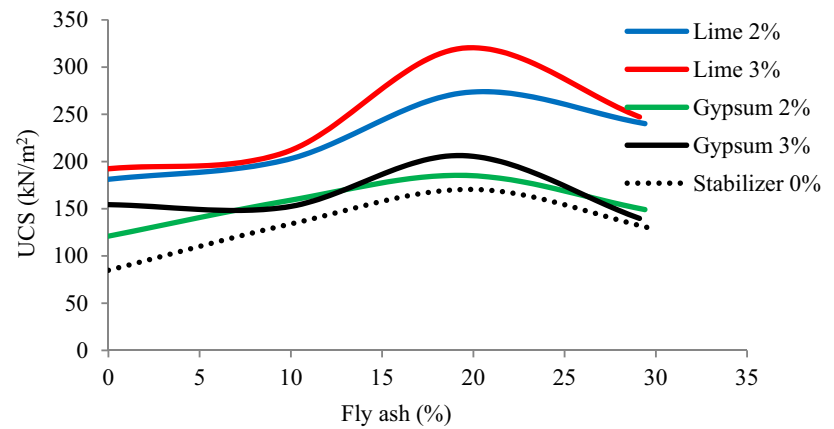

Fig. 10 Variation of unconfined compressive strength with change in fly ash percent at given stabilizer content

attainment of strength when can be used as pavement subgrade.

\subsubsection{Effect of fly ash addition on UCS values of Moorum- Silver sand mixes with and without stabilizers}

Figure 10 represents the effect of UCS strength of moorum-silver sand mixes with and without stabilizers with increasing addition of fly ash content and the trend of changes in UCS values have been found similar typed to the change in CBR values with gradual increase of fly ash content (Fig. 7) with or without addition of stabilizer. In all the cases with addition of stabilizers (i.e. addition of $2 \%$ lime, $3 \%$ lime, $2 \%$ gypsum and $3 \%$ gypsum) the shear strength values got increased almost upto $20 \%$ fly ash content and thereafter UCS values started decreasing. But it has been found that at $19.4 \%$ fly ash content with addition of $3 \%$ lime, the shear strength of moorum-silver sand mix have been obtained maximum.

So, it has been found that $54.32 \%$ moorum mixed with $23.28 \%$ silver sand at $19.4 \%$ fly ash content along with addition of $3 \%$ lime is used pavement subgrade material; it will give the highest result of shear strength and highest resistance to probable rutting failure due to repeated application of moving wheel loads.

\subsection{Correlation between CBR values with UCS test results}

The variation of both the CBR values and unconfined compression strength test values along with fly ash and soil content along with or without adding stabilizers have shown similar patterns, both the experiments of CBR and UCS have been performed on same condition by preparing the soil sample at optimum moisture content (from modified proctor test) in a CBR mould and being kept submerged for 4 days to obtain worst possible field condition and the highest value of both CBR and UCS values have been obtained at $54.32 \%$ moorum mixed with $23.28 \%$ silver sand at $19.4 \%$ fly ash content along with addition of $3 \%$ lime. On this point of view an attempt has been made to correlate the UCS values with CBR values obtained from test results of sample no. 1-20 (Table 12). By performing regression analysis a nonlinear relationship has been obtained, where it has been established that the CBR value of a soil sample can be obtained by knowing the UCS test result of that sample. This correlation has been represented by Eq. 3 .

$\mathrm{CBR}=0.107 \times\left(\frac{q_{u}}{p_{a}}\right)^{1.988}$

It has been found the coefficient of determination $\left(R^{2}\right)$ is 0.963 . In Eq. 3 the term $P_{a}$ is the atmospheric pressure in $\mathrm{kPa}$ (same unit of unconfined compression strength value, $q_{\mathrm{u}}$ ). This constant $P_{\mathrm{a}}$ has been introduced to make the right hand side of the equation unitless. It can be stated that Eq. 3 is dimensionally correct, and it can be used in any unit system. The high coefficient of determination, $R^{2}$ (which is 0.963 ) signifies that Eq. 3 equation gives very well prediction of the CBR values which can be predicted directly from unconfined compression strength $\left(q_{\mathrm{u}}\right)$ test results.

To tally the results obtained from CBR tests and from correlation using Eq. 3 (from UCS test results), the observed $C B R$ values from experiment and predicted value of CBR values (from Eq. 3 ) has been represented in Fig. 11. It has been found that the proposed correlationship approximate the observed CBR value very closely. So it can be stated that this proposed correlation can be used directly to estimate the CBR value of soil sample after determining its unconfined compressive strength.

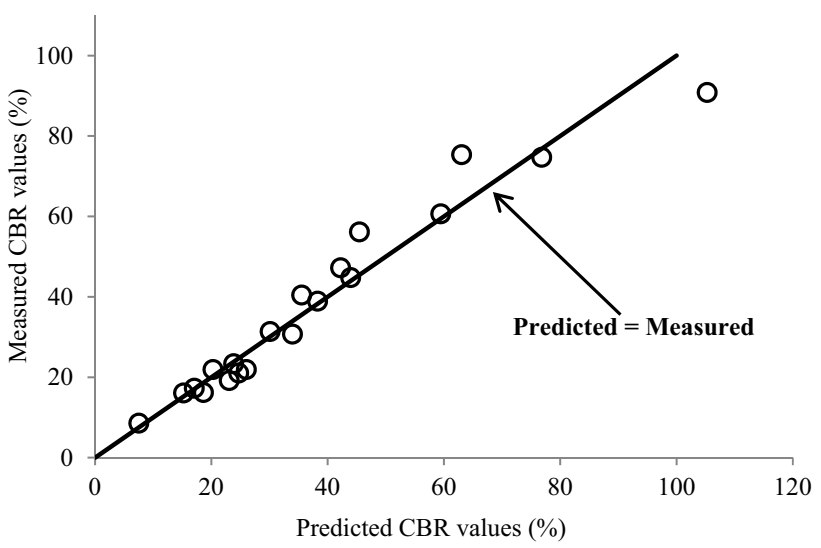

Fig. 11 Comparison between observed CBR values with predicted CBR values from UCS tests 


\subsubsection{Validation of the proposed correlation}

To validate the proposed correlation, a comparative study has been performed between the measured and predicted CBR values for sample no. 21-23, where locally available soil was added along with moorum and silver sand mix and has been shown in Table 14. It has been found that small deviation has been occurred of the calculated CBR values (using Eq. 3) from the experimentally measured CBR values. So, it can be stated that unconfined compression strength test results can be used for a very well prediction of soaked CBR test results after keeping the soil sample immersed under water for 4 days.

\subsubsection{Limitation of the proposed correlation}

The new correlation proposed in this paper based on the experimental observations of unconfined compression strength test and soaked CBR tests has the following limitations:

(1) As the soil skeleton structure, its grain size distribution, mineral constituents, engineering properties and chemical compositions can be found different at different locations, so it can be stated that this new correlation is valid quite well for those types of soil which has the grain size distribution and skeleton structure similar to moorum, silver sand and local soil used in this study.

(2) It has not been clearly understood in case of unsoaked condition this correlation is valid or not. The soil sample prepared in CBR mould without keeping it submerged under water, the proposed correlation between UCS and CBR values may not be valid.

\section{Summary and conclusion}

Most of the studies were done in past for making expansive soil suitable for embankment and subgrade construction work by adding one are more material in to the soil. For utilization of locally available lateritic soil like moorum for sub-base work and relevantly for reusing the wastage

Table 14 Observed and calculated CBR values for sample no. 21-23

\begin{tabular}{llllll}
\hline Sample No & $\begin{array}{l}\text { Moorum } \\
(\%)\end{array}$ & $\begin{array}{l}\text { Silver } \\
\text { Sand } \\
(\%)\end{array}$ & Soil (\%) & $\begin{array}{l}\text { CBR } \\
\text { meas- } \\
\text { ured (\%) }\end{array}$ & $\begin{array}{l}\text { CBR calcu- } \\
\text { lated using } \\
\text { Eq. 3 (\%) }\end{array}$ \\
\hline 21 & 63 & 27 & 10 & 11.97 & 11.85 \\
22 & 56 & 24 & 20 & 12.84 & 11.81 \\
23 & 49 & 21 & 30 & 9.24 & 8.34 \\
\hline
\end{tabular}

SN Applied Sciences

a SPRINGER NATURE journal material from industry, there is a need of detail study on index and engineering properties of local granular lateritic soil with admix of river sand with addition of fly ash along with stabilizer like lime and gypsum on different percentage.

In the present investigation, an attempt has been made to study the improvement in strength of soil subgrade for pavement construction by performing modified proctor tests, CBR tests and unconfined compression strength tests on granular moorum-silver sand mix by replacing a part of it by fly ash and also by stabilizer, i.e. lime and gypsum at different content. CBR tests and unconfined compression strength tests have been performed keeping moorum, silver sand, fly ash and stabilizer with different proportions in standard CBR mould with proper compaction keeping 4-day soaked condition.

The results of the tests obtained have been summarized as:

(1) The modified proctor compaction test results have shown that with increase in fly ash content the MDD values were decreasing. Also it was found that with increase in stabilizer at particular fly ash mix content the MDD value changed in gradual decreasing order.

(2) Swelling percent of moorum-silver sand mix using CBR-instrument was reduced from $5.6-6.2 \%$ to $0.2-$ $0.34 \%$ when fly ash along with lime was added. In order to avoid a pavement heave, $19.4 \%$ fly ash along with $3 \%$ lime should be added with the existing soil subgrade material.

(3) Soil specimens in CBR mould have been compacted at the optimum water content and tested at 4-day soaked condition. It was found that with increase in fly ash content in moorum silver sand mix CBR value increasing up to $20 \%$ after that it gives comparatively low CBR value.

(4) When lime is used as a stabilizer, it gives much higher CBR value compared to gypsum. When $3 \%$ lime content has been added in combination of $19.4 \%$ fly ash $+77.6 \%$ conventional moorum sand mix, it gives maximum CBR value of $90.84 \%$. On the other hand, for the same combination $3 \%$ gypsum gives only $44.76 \%$ CBR value.

(5) It has been also found that if fly ash can be used as a replacement of soil in moorum sand conventional mix it gives higher CBR value.

(6) The test results of unconfined compression strength tests have shown almost similar pattern of change in behaviour of experimental results obtained from soaked CBR tests.

(7) In addition of fly ash content, the UCS value has increased upto $20 \%$ and thereafter starts decreasing, whereas very less gradual increase in UCS value 
in addition of local soil content upto $13 \%$ has been observed and thereafter it starts decreasing. Without adding any stabilizer just only using fly ash / soil with replacement of moorum-silver sand conventional $\mathrm{mix}$, it has been observed that UCS value has been increased from $84.8 \mathrm{kN} / \mathrm{m}^{2}$ to $170.47 \mathrm{kN} / \mathrm{m}^{2}$ in case of fly ash, whereas only an increase of $84.8 \mathrm{kN} / \mathrm{m}^{2}$ $106.67 \mathrm{kN} / \mathrm{m}^{2}$ UCS value has been obtained in case of local soil used. So fly ash can be used as better replacement material than local soil.

(8) From CBR tests as well unconfined compression strength tests, it can be commented that the best suitable and highest effective composition of pavement subgrade material should be $54.32 \%$ moorum mixed with $23.28 \%$ silver sand at $19.4 \%$ fly ash content along with addition of $3 \%$ lime. Lime acts as a good binding material by its cementing action which makes a good bond between moorum-silver sand and fly ash.

(9) Based on experimental results, a good correlation between UCS values and CBR values of soaked soil samples (kept in submerged in water for 4 days) has been established which indicates that the CBR value of soil can be well predicted from UCS test results.

\section{Recommendation for future work}

From this test experimental study, the future scope of work can be commented that the similar nature of investigations is recommended for other stabilizers like kaolinite clay, bentonite, bitumen etc. and for other waste materials like construction garbage, rice husk ash (obtained as byproduct from rice mills) etc.

Acknowledgements The authors would like to thank Department of Civil Engineering, Techno India University, West Bengal for providing permission for utilization of the laboratory facilities along with supporting manpower. The authors are highly thankful to Civil Engineering Department of Techno India University, West Bengal for providing sufficient financial supports for collection of all three types of soil samples, i.e. moorum, silver sand and local soil along with arrangement of fly ash, lime and gypsum which were essential for preparing soil samples to conduct the laboratory experiments.

Author contributions All authors contributed to the study conception and design. Material preparation, data collection and analysis were performed by PR, AP, SG, KS and RNS. The first draft of the manuscript was written by Prof. PR and all authors commented on previous versions of the manuscript. All authors read and approved the final manuscript.

\section{Compliance with ethical standards}

Conflict of interest The authors declare that they have no conflict of interest.
Availability of data and material The material has been collected by the corresponding author, Mr. Pinak Ray, from the site and all the relevant data regarding the material has been determined and generated by experimental works in the Soil Mechanics Laboratory of Department of Civil Engineering, Techno India University, West Bengal, Kolkata-700091, West Bengal, India.

\section{References}

1. Osinubi K (2000) Stabilisation of tropical black clay with cement and pulverized coal bottom ash admixture. Adv Unsaturated Geotech. https://doi.org/10.1061/40510(287)20

2. Cokca $E$ (2001) Use of class $C$ fly ashes for the stabilization of an expansive soil. J Geotech Geoenviron Eng 127(7):568-573

3. Pandian NS, Krishna KC, Leelavathamma B (2002) Effect of Fly Ash on the CBR Behaviour of Soils. Proceedings of Indian Geotechnical Conference, Allahabad 183-186

4. Manjesh L, Ramesh NH, Mohan HK, Sivapullaiah VP (2003) CBR values of soil-fly ash mixture for road construction. Proceedings of Indian Geotechnical Conference, Roorkee 451-454

5. Kaushik PN, Sharma KJ, Prasad DC (2003) Effect of fly ash and lime- fly ash on characteristics of expansive soils. Proceedings of Indian Geotechnical Conference, Roorkee 459-462

6. Kolias S, Karahalios A (2005) Stabilization of clayey soils with high calcium fly ash and cement. Cement Concr Compos 27(2):301-313

7. Degirmenci N, Okucu A, Turabi A (2007) Application of phosphogypsum in soil stabilization. Build Environ 42(9):3393-3398

8. Harichane K, Ghrici M, Kenai S (2011) Effect of curing time on shear strength of cohesive soils stabilized with combination of lime and natural pozzolana. Int J Civil Eng 9(2):90-96

9. Chand S, Subbarao C (2007) Strength and slake durability of lime stabilized pond ash. J Mater Civ Eng 19(7):601-608

10. Ahmad I, Mahanwar PA (2010) Mechanical properties of Fly Ash filled high density polyethylene. J Miner Mater Charact Eng 9(3):183-198

11. Sridharan A (2012) Coal ashes in geotechnical engineering practice beneficial aspects. Workshop on emerging trends in geotechnical engineering (ETGE 2012), Guwahati 11-25

12. IS 2720 part-4 (1985) Code of practice for grain size analysis. Bureau of Indian Standards, New Delh

13. IS 2720 part-16 (1987) Code of practice for laboratory CBR test. Bureau of Indian Standards, New Delhi

14. IS 2720 part-8 (1983) Code for determination of water contentdry density relation using heavy compaction. Bureau of Indian Standards, New Delhi

15. IS 2720 part-2 (1973) Code of practice for determination of water content. Bureau of Indian Standards, New Delhi

16. IS 2720 part-10 (1991) Code of practice for determination of unconfined compressive strength. Bureau of Indian Standards, New Delhi

17. IS 2720 part-3 (1980) Code of practice for determination of specific gravity. Bureau of Indian Standards, New Delhi

18. IS 1498 (1970) Code of practice for Identification and classification of soil. Bureau of Indian Standards, New Delhi

19. IS 2720 part-5 (1985) Code of practice for determination of Atterberg Limits. Bureau of Indian Standards, New Delhi

Publisher's Note Springer Nature remains neutral with regard to jurisdictional claims in published maps and institutional affiliations. 